\title{
KREATIVITAS GURU DALAM PEMBELAJARAN BERBASIS DARING DI PAUD ISLAM TERPADU ANAK MANDIRI KOTA PALU DI MASA PANDEMI COVID-19
}

\author{
Madrika $^{1)}$ Rusdin ${ }^{2)}$ Jumri H. Tahang ${ }^{3)}$ \\ ${ }^{1}$ Mahasiswa Program Studi PIAUD FTIK Institut Agama Islam Negeri Palu \\ ${ }^{2}$ Dosen Fakultas Tarbiyah dan Ilmu Keguruan Institut Agama Islam Negeri Palu \\ ${ }^{3}$ Dosen Fakultas Tarbiyah dan Ilmu Keguruan Institut Agama Islam Negeri Palu
}

\begin{abstract}
ABSTRAK
Penelitian ini membahas tentang kreativitas guru dalam pembelajaran berbasis daring di PAUD Islam Terpadu Anak Mandiri Kota Palu di masa pandemic covid 19. Penelitian ini menggunakan pendekatan kualitatif. Teknik pengumpulan data melalui observasi, wawancara dan dokumentasi. Teknik analisis data yang digunakan adalah reduksi data, penyajian data dan verifikasi data. Berdasarkan hasil penelitian, diperoleh bahwa kreativitas guru dalam pembelajaran berbasis daring pada masa pandemi covid-19 di PAUD Islam Terpadu Anak Mandiri Kota Palu yaitu dapat dilihat dari kreativitas guru dalam manajemen kelas seperti mengelola dan menyusun perencanaan kegiatan pembelajaran yang dilakukan melalui kelas daring dengan membuat grup kelas di aplikasi whatsapp dan membuat video pembelajaran kemudian dikirim ke grup kelas yang telah dibuat, dan kreativitas guru dalam memanfaatkan media pembelajaran yang ada di lingkungan sekitar, penggunaan media pembelajaran dapat mempermudah guru dalam menjelaskan materi pembelajaran yang diberikan dan penggunaan media pembelajaran yang bervariasi dan sesuai dengan materi yang diajarkan akan membuat peserta didik tertarik untuk belajar serta cepat paham dengan materi yang disampaikan. Adapun yang menjadi faktor pendukung kreativitas guru dalam pembelajaran berbasis daring di PAUD Islam Terpadu Anak Mandiri Kota Palu yaitu ketersediaan sarana prasarana di sekolah, kerja sama sesama guru dan mengikuti program webinar. Sedangkan faktor penghambat kreativitas guru dalam pembelajaran berbasis daring di PAUD Islam Terpadu Anak Mandiri Kota Palu yaitu Keterbatasan waktu dalam membuat video pembelajaran, terbatasnya memori penyimpanan di HP dan gangguan jaringan yang mengakibatkan proses pembelajaran menjadi terhambat.
\end{abstract}

Kata Kunci : Kreativitas Guru, Pembelajaran Berbasis Daring, Pandemi Covid-19.

\section{PENDAHULUAN}

Kreativitas merupakan hal yang sangat penting dalam pembelajaran, dan guru dituntut untuk mendemonstrasikan dan menunjukkan proses kreativitas tersebut, kreativitas ditandai dengan adanya kegiatan menciptakan sesuatu yang sebelumnya 
tidak ada dan tidak dilakukan oleh seseorang atau adanya kecenderungan untuk menciptakan sesuatu. Kreativitas guru dalam proses pembelajaran merupakan suatu kemampuan yang dimiliki seorang guru dalam mengolah pembelajaran dalam usahanya mencapai tujuan pendidikan yang diharapkan. Kemampuan guru dalam mengolah pembelajaran yaitu dengan merumuskan persiapan mengajar, kegiatan pembelajaran, memilih dan menerapkan metode pengajaran yang tepat dan sesuai, mampu berinteraksi dengan peserta didik secara baik, sehingga dapat menciptakan situasi belajar dan merangsang peserta didik untuk selalu aktif terlibat dalam mengikuti pelajaran.

Kreativitas menjadi unsur penting dalam menyukseskan pengajaran. Tanpa kreativitas, pembelajaran akan terasa jenuh dan potensi anak tidak berkembang dengan baik, terlebih dalam suasana pembelajaran pada masa pandemi covid-19. Sejak mewabahnya virus baru yang diberi nama COVID-19 (Corona Virus Disease19) di Indonesia sejak awal maret 2020, maka pemerintah Indonesia mengeluarkan berbagai kebijakan untuk mencegah semakin mewabahnya virus COVID-19 tersebut, salah satunya dengan menerapkan sistem Social Distancing (Pembatasan interaksi sosial). Wabah COVID-19 membuat banyak kegiatan publik beralih dengan pusat aktivitas utamanya berada dirumah. Situasi ini merupakan realitas baru yang juga dialami dunia pendidikan utamanya terjadi pada pengajaran Pendidikan Anak Usia Dini (PAUD).

Undang-undang Nomor 20 Tahun 2003 sistem pendidikan Nasional berkaitan dengan pendidikan anak usia dini tertulis pada pasal 28 ayat I bahwa Pendidikan anak usia dini diselenggarakan bagi anak sejak lahir sampai dengan anak usia enam tahun dan bukan merupakan prasyarat untuk mengikuti pendidikan dasar. ${ }^{1}$ Pendidikan Anak Usia Dini merupakan salah satu tahapan pendidikan yang dapat menentukan pertumbuhan dan perkembangan anak dimasa depannya. ${ }^{2}$ Pendidikan Anak Usia Dini dapat diselenggarakan melalui jalur pendidikan formal meliputi Taman KanakKanak (TK), dan Raudhatul Athfal (RA), pada jalur non formal meliputi Kelompok Bermain (KB), dan Taman Penitipan Anak (TPA), sementara jalur pendidikan informal meliputi pendidikan keluarga. Pendidikan Anak Usia Dini perlu mendapatkan perhatian yang sungguh-sungguh dari pemerintah dan masyarakat karena merupakan langkah awal untuk menuju pendidikan yang lebih lanjut.

Pendidikan Anak Usia Dini merupakan salah satu tahapan pendidikan yang tidak dapat diabaikan karena ikut menentukan perkembangan dan keberhasilan anak. Seiring perkembangan pemikiran tersebut, tuntutan dan kebutuhan layanan

${ }^{1}$ Yuliani Nurani Sujiono, Konsep Dasar Anak Usia Dini (cet,II; Jakarta: Indeks,2010), 34 2015) 2 .

${ }^{2}$ Suyadi, Maulidya Ulfah, Konsep Dasar PAUD, (Bandung: PT. Remaja Rosda Karya, 
pendidikan anak usia dini cenderung semakin meningkat dan berpengaruh pada kualitas penyelenggaraan lembaga pendidikan anak usia dini. Sehingga upaya pemerintah dalam mengurangi angka penyebaran Covid-19 dan kegiatan pendidikan dapat berjalan seperti biasanya maka pemerintah melakukan beberapa upaya untuk mengurangi angka tersebut yang salah satunya diterapkan dalam sistem pendidikan di Indonesia. Pelaksanaan kegiatan belajar mengajar dilaksanakan dengan sistem dalam jaringan (daring) dan sistem luar jaringan (luring). Sistem pembelajaran daring, dilakukan tanpa tatap muka secara langsung, melainkan dilakukan dengan sistem pembelajaran jarak jauh. Dengan sistem pembelajaran jarak jauh, peserta didik tidak diharuskan atau diwajibkan untuk datang ke sekolah maupun kampus untuk melaksanakan pembelajaran. Banyak sarana yang pada akhirnya diterapkan oleh tenaga pendidik untuk melaksanakan kegiatan belajar mengajar secara jarak jauh. Sarana pembelajaran jarak jauh tersebut tidak dapat dihindari dari perkembangan teknologi informasi dan komunikasi. Sarana pembelajaran tersebut di antaranya aplikasi google meet, aplikasi zoom, google classroom, youtube, televisi, maupun media sosial whatsapp. Di mana semua sarana tersebut dihasilkan dari perkembangan teknologi informasi dan komunikasi yang semakin maju, sehingga peran guru sangat penting dalam proses pembelajaran dimasa pandemi covid-19.

Guru merupakan salah satu unsur dalam penyelenggaraan sistem pendidikan di sekolah. Guru memiliki peran yang sangat penting dalam membentuk, membina serta mencapai hasil pendidikan dan peningktan mutu. Peran guru kerap kali menjadi sumber inti dalam mentransformasi nilai-nilai ilmu pengetahuan maupun nila-nilai lainnya kepada peserta didik sehingga kemampuan, pengetahuan dan keterampilan yang dimiliki oleh guru mendominasi proses pembelajaran dan pembentukan hasil belajar terhadap peserta didik. ${ }^{3}$ Guru sebagai seorang pendidik merupakan salah satu faktor penentu keberhasilan dalam mencapai tujuan pendidikan dan peningkatan mutu.

Permasalahan dalam dunia pendidikan kaitannya dengan guru yang sering ditemukan adalah kurangnya kreativitas guru dalam mengajar. Guru yang kurang kreatif dalam mengajar menjadikan pembelajaran berjalan monoton, sehingga menimbulkan kejenuhan pada peserta didik. Guru terkadang hanya fokus pada pemenuhan tahapan pembelajaran dan materi yang harus disampaikan, tanpa

3 Yanti Oktavia, "Usaha Kepala Sekolah dalam Meningkatkan Kreativitas Guru dalam Pembelajaran di Sekolah,” Jurnal Admistrasi Pendidikan, 2 No. 1 (2014): 808.

https://scholar.google.co.id/scholar?hl=id\&as_sdt=0\%2C5\&q=usaha+kepala+sekolah+dalam+ meningkatkan+kreativitas+guru\&btnG=\#d=gs_qabs\&u=\%23p\%3D2jsem2x45DwJ. (Diakses, Rabu 21 oktober 2020). 
memikirkan strategi atau cara terbaik untuk keberhasilan dalam pembelajaran. Guru mengajar hanya sekedar menggugurkan kewajiban tanpa memastikan pemahaman semua peserta didiknya dari materi yang telah diajarkan.

Guru sebagai seorang pendidik merupakan salah satu faktor penentu keberhasilan dalam mencapai tujuan pendidikan itu sendiri. Dalam kaitannya dengan proses pembelajaran pada masa pandemik covid 19, guru dituntut harus lebih kreatif dalam menyajikan materi-materi pelajaran dengan keterbatasan waktu dan tempat serta harus tetap memperhatikan protokol kesehatan. Guru yang memiliki kreativitas dalam mengajar menjadikan pembelajaran menjadi berkualitas. Pembelajaran menjadi efektif, suasana pembelajaran menjadi asyik dan menyenangkan, serta pembelajaran tidak membuat peserta didik mengalami kejenuhan. Guru yang kreatif tentunya memiliki modal wawasan yang luas dan menguasai banyak metode pembelajaran sehingga mampu memilih metode dan media pembelajaran dengan tepat. Penggunaan media pembelajaran yang tepat akan sangat membantu keefektifan proses pembelajaran dalam menyampaikan pesan dan isi pelajaran pada saat itu, guru juga harus berkepribadian baik sehingga mampu menjadi contoh bagi para peserta didiknya. Jadi, guru merupakan sosok yang sangat berpengaruh pada keberhasilan peserta didik dalam menguasai materi pelajaran.

Dari hasil observasi awal di PAUD Islam Terpadu Anak Mandiri kota Palu terlihat bahwa pelaksanaan pembelajaran kurang terlaksana secara efektif dan peserta didik masih kurang memahami materi pelajaran yang diberikan, dikarenakan masih kurangnya kreativitas guru dalam pembelajaran berbasis daring.

\section{METODE PENELITIAN}

Jenis penelitian yang digunakan dalam penelitian ini adalah penelitian kualitatif. Lokasi penelitian yakni di PAUD Islam Terpadu Anak Mandiri Kota Palu. Pemilihan lokasi ini didasarkan pada beberapa alasan peneliti yaitu lokasi penelitian relatif terjangkau dan lokasi penelitiannya belum pernah diteliti oleh mahasiswa lain serta peneliti ingin mengetahui kreativitas guru dalam pembelajaran berbasis daring pada masa pandemi covid 19 di PAUD Islam Terpadu Anak Mandiri Kota Palu.

Teknik pengumpulan data yang digunakan adalah teknik observasi, dokumentasi dan wawancara. Adapun teknik analisis data yang dilakukan meliputi reduksi data, penyajian data dan verifikasi data. Data-data yang telah didapatkan dari lokasi penelitian sangat penting untuk dicek kembali, agar benarbenar memperoleh data yang akurat sesuai harapan. Empat kriteria yang menunjukkan keabsahan suatu data, yang menurut Lexy J. Moelong adalah derajat kepercayaan (credibility), keteralihan (transferability), ketergantungan 
(dependability) dan kepastian (konfirmality). ${ }^{4}$ Selanjutnya, untuk mengecek keabsahan data yang diperoleh maka dilakukan tehnik pemeriksaan atau pengecekan data yang memanfaatkan sesuatu yang lain, diluar data itu untuk keperluan pengecekan dan perbandingan. Menurut sugiyono, Tiga macam triangulasi sebagai tehnik pemeriksaan yaitu triangulasi dengan sumber, triangulasi dengan tehnik pengumpulan data, triangulasi waktu. ${ }^{5}$

\section{HASIL DAN PEMBAHASAN}

\section{A. Kreativitas Guru dalam Pembelajaran Berbasis Daring di PAUD Islam Terpadu Anak Mandiri Kota Palu di Masa Pandemi Covid-19}

Kreativitas merupakan hasil interaksi antara individu dan lingkungannya. Seseorang mempengaruhi dan dipengaruhi oleh lingkungan dimana ia berada, dengan demikian baik perubahan di dalam individu maupun di dalam lingkungan dapat menunjang atau dapat penghambat upaya kreatif. ${ }^{6}$ Pada kegiatan pembelajaran di PAUD Islam Terpadu Anak Mandiri kota Palu, guru berperan sangat penting dalam proses pembelajaran terlebih lagi pada masa pandemi covid-19, yang mana proses pembelajaran secara tatap muka dihentikan untuk sementara waktu dan diganti dengan proses pembelajaran secara daring, sehingga kreativitas guru dalam pembelajaran daring sangat diperlukan agar pembelajaran menjadi berkualitas, efektif dan suasana pembelajaran menjadi asyik dan menyenangkan, serta pembelajaran tidak membuat peserta didik mengalami kejenuhan. Guru tidak hanya dituntut kreatif dalam proses pembelajaran daring saja, tetapi guru juga memiliki bentuk kreativitas sebagai berikut:

1. Kreativitas Guru dalam Manajemen Kelas

Manajemen kelas adalah aktivitas guru dalam megelola dinamika kelas, mengorganisasikan sumber data yang ada serta menyusun perencanaan aktivitas yang dilakukan dikelas untuk diarahkan dalm proses pembelajaran yang baik. Dalam hal manajemen kelas, kreativitas guru diarahkan untuk membantu peserta didik di kelas agar dapat belajar secara kolaboratif dan kooperatif serta menciptakan lingkungan akademik yang kondusif dalam proses belajar. ${ }^{7}$ Dalam hal manajemen kelas pada pembelajaran daring yang dilakukan di PAUD Islam Terpadu Anak Mandiri kota Palu yaitu guru membuat perencanaan pembelajaran setiap minggu untuk satu kali pertemuan dalam bentuk Rencana Pelaksanaan Pembelajaran Mingguan (RPPM),

\footnotetext{
${ }^{4}$ Lexy J. Moleong, Metodologi Penelitian Kualitatif (Bandung : Rosdakarya, 2010), 115

5 Sugiyono, Metode Penelitian Pendidikan Pendekatan Kuantitaf, Kualitatif Dan R\&D (Cet.XX;Bandung: Alfabet, 2014), 179.

${ }^{6}$ Utami Munandar, Perkembangan Kreativitas Anak Berbakat (Jakarta: Rineka Cipta 2004), 12.

${ }^{7}$ E. Mulyasa, Menjadi Guru Profesionl, Menciptakan Pembelajaran Kreatif dan Menyenangkan (Cet.IX; Bandung, 2010), 45-46.
} 
mempersiapkan kegiatan pembelajaran, memilih dan menerapkan metode pengajaran yang tepat dan sesuai dengan materi pelajaran yang diberikan serta menyiapkan media pembelajaran untuk dibagikan ke peserta didik. Sebagaimana hasil wawancara dari guru kelas B1 sebagai berikut:

Selama masa pandemi ini kami para guru membuat perencanaan pembelajaran setiap minggunya dan kami juga menyiapkan media pembelajaran untuk peserta didik seperti lembar kerja, pensil warna dan media lainnya yang sesuai dengan materi ajar yang akan diberikan, serta kami juga membuat grup kelas di aplikasi whatsapp untuk mempermudah berkomunikasi dengan orang tua peserta didik dan dari grup whatsapp itu juga kami menyampaikan segala informasi terkait pembelajaran maupun info-info lainnya yang berkaitan dengan urusan sekolah. ${ }^{8}$

Pernyataan di atas menunjukkan bahwa guru di PAUD Islam Terpadu Anak Mandiri melakukan kreativitas pembelajaran dalam mengatur, mengelola dan menyusun perencanaan kegiatan pembelajaran yang dilakukan melalui kelas daring dengan membuat video pembelajaran kemudian dikirim ke grup kelas masing-masing serta guru menyiapkan segala keperluan yang dibutuhkan oleh peserta didik untuk belajar di rumah.

\section{Kreativitas Guru dalam Pemanfaatan Media Pembelajaran}

Media pembelajaran adalah sebuah alat untuk membantu guru dalam memberikan pemahaman cepat kepada peserta didik untuk menjelaskan maksud dari pembahasan pembelajaran yang disampaikan. Berikut hasil wawancara yang penulis lakukan terhadap guru kelas B1:

Dalam proses pelaksanaan pembelajaran secara daring, kami para guru itu menggunakan media pembelajaran dengan memanfaatkan barang-barang yang dapat dijangkau oleh peserta didik, misalnya pada pembelajaran menghitung saya menugaskan peserta didik untuk menghitung benda yang ada di dalam rumah seperti menghitung jumlah sendok yang ada didapur atau menghitung jumlah bantal yang ada dikamar, tapi sebelum saya memberikan tugas, saya terlebih dahulu memberikan contoh kepada peserta didik melalui video pembelajaran yang diberikan. Selain itu saya juga menyediakan media pembelajaran di kertas hvs dengan tulisan angka dan gambar benda yang sesuai dengan jumlah angka kemudian peserta didik menghubungkan angka dan jumlah gambar yang ada. ${ }^{9}$

${ }^{8}$ Fitriana, Guru Kelas B1, "Wawancara” di ruangan kelas B1 PAUD Islam Terpadu Anak Mandiri Kota Palu, tanggal 10 Maret 2021.

${ }^{9}$ Fitriana, Guru Kelas B1, "Wawancara" di ruangan kelas B1 PAUD Islam Terpadu Anak Mandiri Kota Palu, tanggal 10 Maret 2021. 
Media yang digunakan dalam pembelajaran daring sangat mudah dijangkau oleh peserta didik dengan memanfaatkan media pembelajaran yang ada disekitar rumah dan tidak mengeluarkan biaya untuk mendapatkannya. Selain dari memanfaatkan media pembelajaran yang ada di rumah guru juga tetap menyediakan media pembelajaran di sekolah. Sebagimana hasil wawancara dari guru kelas B2 sebagai berikut:

Kami dari pihak sekolah tidak mengharapkan sepenuhnya media pembelajaran yang ada dirumah, seperti pembelajaran yang mengharuskan menggunakan kertas origami, pensil warna dan media gambar yang sesuai dengan materi yang akan diajarkan, kami dari pihak sekolah tetap menyediakan media tersebut, karena saya juga beranggapan bahwa penggunaan media pembelajaran yang bervariasi dapat menarik minat anak untuk belajar, anak cepat paham dan tidak membuat anak bosan dalam menerima pelajaran. ${ }^{10}$

Penggunaan media dalam proses pembelajaran hendaknya bervariasi dan tetap sesuai dengan materi yang diajarkan agar proses belajar mengajar dapat terlaksana dengan baik serta penggunaan media pembelajaran yang tepat akan turut menentukan tingkat keberhasilan proses pembelajaran, begitu juga halnya dalam menjelaskan materi pelajaran, peserta didik akan cepat tanggap serta memahami materi pelajaran yang diberikan.

\section{B. Faktor Pendukung dan Penghambat Kreativitas Guru dalam Pembelajaran Berbasis Daring di PAUD Islam Terpadu Anak Mandiri Kota Palu di Masa Pandemi Covid-19}

1. Faktor Pendukung

Faktor pendukung merupakan hal yang tidak bisa dilupakan dalam sebuah kreativitas, karena pada dasarnya faktor pendukung mampu menjadikan sebuah kreativitas berjalan sesuai dengan fungsi sesungguhnya, walaupun tidak seratus persen. Di antara faktor-faktor pendukung yang menunjang keberhasilan kreativitas guru pada pembelajaran berbasis daring di PAUD Islam Terpadu Anak Mandiri Kota Palu di masa pandemi covid-19 adalah sebagai berikut:

a. Sarana dan Prasarana Sekolah

Ketersediaan sarana prasarana pembelajaran di sekolah sangatlah membantu dan menunjang pelaksanaan pendidikan terlebih lagi pada masa pandemi covid-19 dengan diterapkannya sistem pembelajaran daring yang otomatis mengharuskan semua guru yang ada di sekolah untuk menggunakan jaringan internet sebagai alat

\footnotetext{
${ }^{10}$ Carolin Izaac, Guru Kelas B2, "Wawancara" di ruangan kelas B2 PAUD Islam Terpadu Anak Mandiri Kota Palu, tanggal 15 Maret 2021.
} 
untuk berkomunikasi dengan peserta didiknya, maka dari itu penting adanya fasilitas wifi yang harus disediakan di sekolah. Berikut hasil wawancara dari guru kelas B2:

Kami para guru membuat video pembelajaran di sekolah dan dikirim ke grup wa dengan fasilitas jaringan wifi yang ada di sekolah, dan fasilitas wifi ini mempermudah kami para guru dalam berkomunikasi dengan anak melalui perantara orang tuanya dan mengurangi biaya kami dalam membeli paket data. $^{11}$

Pernyataan di atas dapat disimpulkan bahwa di sekolah PAUD Islam Terpadu Anak Mandiri Kota Palu telah menyediakan fasilitas wifi untuk mempermudah guru dalam melakukan proses pembelajaran secara daring.

b. Kerjasama sesama guru

Salah satu penunjang kreativitas guru dalam pembelajaran daring ialah kerja sama sesama guru dalam membuat perangkat pembelajaran maupun hal-hal lainnya yang berkaitan dengan proses pembelajaran untuk mencapai tujuan pembelajaran yang diinginkan. Sebagaimana hasil wawancara dari guru kelas B1 sebagai berikut:

Kami para guru selalu sharing mengenai pelajaran, kami juga dalam menyusun dan membuat PROSEM, RPPM dan perangkat pembelajaran lainnya kami selalu bekerja sama, dan terkadang kami juga saling memberikan masukan mengenai pemakaian media yang cocok dengan materi yang diajarkan. ${ }^{12}$

Penjelasan di atas disimpulkan bahwa guru di PAUD Islam Teerpadu Anak Mandiri Kota Palu saling bekerja sama dalam membuat dan menyusun perangkat pembelajaran dan saling memberikan masukan tekait media pembelajaran yang cocok digunakan, agar proses pembelajaran berjalan dengan lancar dan mencapai tujuan pembelajaran yang di inginkan.

\section{c. Mengikuti Program Webinar}

Webinar merupakan seminar yang dilakukan melalui situs web atau aplikasi berbasis internet. Pada masa pandemi covid-19 ini, salah satu cara guru untuk meningkatkan kemampuan dalam merancang dan mengelola pembelajaran jarak jauh ialah dengan mengikuti program webinar yang dilaksanakan oleh dinas pendidikan terkait. Sebagaimana hasil wawancara dari ibu Carolin Izaac selaku guru kelas B2:

\footnotetext{
${ }^{11}$ Carolin Izaac, Guru Kelas B2, "Wawancara” di ruangan kelas B2 PAUD Islam Terpadu Anak Mandiri Kota Palu, tanggal 15 Maret 2021.

12 Fitriana, Guru Kelas B1, "Wawancara" di ruangan kelas B1 PAUD Islam Terpadu Anak Mandiri Kota Palu, tanggal 10 Maret 2021.
} 
Pada masa pandemi ini kami para guru mengikuti webinar ataupun pelatihan mengenai pembelajaran pada masa pandemi dengan aplikasi zoom, dipelatihan tersebut kami diajarkan cara menyusun PROSEM dan RPPM, serta penggunaan media pembelajaran dengan memanfaatkan benda yang ada disekitar tempat tinggal kita. ${ }^{13}$

Kegiatan webinar yang diikuti oleh guru-guru yang ada di PAUD Islam Terpadu Anak Mandiri Kota Palu sangat membantu dalam proses pembelajaran secara daring.

\section{Faktor Penghambat}

Faktor penghambat kreativitas guru dalam pembelajaran daring pada masa pandemi covid-19, Sebagaimana yang diungkapkan oleh ibu Carolin Izaac selaku guru kelas B2 sebagai berikut:

Dalam pembelajaran daring ini ada beberapa faktor yang menjadi penghambat kreativitas guru seperti yang pertama itu keterbatasan waktu membuat video, dimana kami para guru membuat video pembelajaran dengan durasi yang singkat karena mengingat terbatasnya memori penyimpanan di hp dan juga video pembelajaran yang berdurasi panjang akan lambat terkirim digrup wa, yang kedua terbatasnya memori penyimpanan di hp yang membuat sebagian orang tua peserta didik mengeluh karena kadang hpnya sudah mulai lambat respon kalau dipakai dan yang ketiga gangguan ja ringan, ini sering terjadi karena semua guru yang ada di sekolah menggunakan jaringan wifi, apalagi semuanya bersamaan online, jadi terkadang jaringan wifi sekolah mengalami gangguan atau lambat mengirim video pembelajaran. ${ }^{14}$

Dari hasil wawancara di atas penulis dapat simpulkan bahwa ada beberapa faktor penghambat kreativitas guru dalam pembelajaran daring pada masa pandemi covid-19 di PAUD Islam Terpadu Anak Mandiri Kota Palu yakni keterbatasan waktu dalam membuat video pembelajaran, terbatasnya memori penyimpanan HP, dan gangguan jaringan yang mengakibatkan proses pembelajaran menjadi terhambat.

\footnotetext{
${ }^{13}$ Carolin Izaac, Guru Kelas B2, "Wawancara" di ruangan kelas B2 PAUD Islam Terpadu Anak Mandiri Kota Palu, tanggal 15 Maret 2021.

${ }^{14}$ Carolin Izaac, Guru Kelas B2, "Wawancara" di ruangan kelas B2 PAUD Islam Terpadu Anak Mandiri Kota Palu, tanggal 15 Maret 2021.
} 


\section{KESIMPULAN}

Berdasarkan hasil pembahasan dalam penelitian ini, maka penulis dapat mengemukakan beberapa kesimpulan sebagai berikut:

1. Kreativitas guru dalam pembelajaran berbasis daring pada masa pandemi covid-19 di PAUD Islam Terpadu Anak Mandiri Kota Palu yaitu dapat dilihat dari kreativitas guru dalam manajemen kelas seperti mengelola dan menyusun perencanaan kegiatan pembelajaran yang dilakukan melalui kelas daring dengan membuat grup kelas di aplikasi whatsapp dan membuat video pembelajaran kemudian di kirim ke grup kelas yang telah dibuat, dan kreativitas guru dalam memanfaatkan media pembelajaran yang ada di lingkungan sekitar, penggunaan media pembelajaran dapat mempermudah guru dalam menjelaskan materi pembelajaran yang diberikan dan penggunaan media pembelajaran yang bervariasi dan sesuai dengan materi yang diajarkan akan membuat peserta didik tertarik untuk belajar serta cepat paham dengan materi yang disampaikan.

2. Faktor pendukung kreativitas guru dalam pembelajaran berbasis daring di PAUD Islam Terpadu Anak Mandiri Kota Palu, yaitu ketersediaan sararana prasarana sekolah, adanya kerja sama sesama guru, dan mengikuti program webinar. Sedangkan factor penghambatnya yakni keterbatasan waktu dalam membuat video pembelajaran, terbatasnya memori penyimpanan $\mathrm{HP}$, dan gangguan jaringan yang mengakibatkan proses pembelajaran menjadi terhambat.

\section{SARAN}

Sebagai tindak lanjut penelitian yang Penulis lakukan maka ada beberapa saran sebagai berikut:

1. Bagi pembaca diharapkan dapat menambah wawasan dan ilmu tentang Kreativitas guru dalam pembelajaran berbasis daring pada masa pandemi covid-19.

2. Bagi sekolah agar selalu memberikan dorongan dan fasilitas kepada guru dalam mengembangkan kreativitas yang dimiliki untuk menunjang keberhasilan dalam sebuah proses pembelajaran.

3. Bagi guru agar selalu menambah dan membuat inovasi baru terkait proses pembelajaran secara daring maupun proses pembelajaran lainnya, agar kreativitas guru dalam proses pembelajaran selalu berkembang. 


\section{DAFTAR PUSTAKA}

Moleong, Lexy J. Metodologi Penelitian Kualitatif. Bandung : Rosdakarya, 2010.

Mulyasa, E. Menjadi Guru Profesional, Menciptakan Pembelajaran Kreatif dan Menyenangkan. Cet.IX; Bandung, 2010.

Munandar, Utami. Perkembangan Kreativitas Anak Berbakat. Jakarta: Rineka Cipta 2004.

Oktavia, Yanti. "Usaha Kepala Sekolah dalam Meningkatkan Kreativitas Guru dalam Pembelajaran di Sekolah,” Jurnal Admistrasi Pendidikan, 2 No. 1 (2014): 808.

Sugiyono, Metode Penelitian Pendidikan Pendekatan Kuantitaf, Kualitatif Dan $R \& D$. Cet.XX;Bandung: Alfabet, 2014.

Sujiono, Yuliani Nurani. Konsep Dasar Anak Usia Dini. Cet,II; Jakarta: Indeks, 2010.

Suyadi, Maulidya Ulfah, Konsep Dasar PAUD, Bandung: PT. Remaja Rosda Karya, 2015. 